\title{
TURNING WATER INTO WELLBEING
}

How an irrigation scheme changed lives in a Zimbabwean dryland

Lessons from a mixed-methods evaluation of Oxfam's Ruti Irrigation Project in Zimbabwe

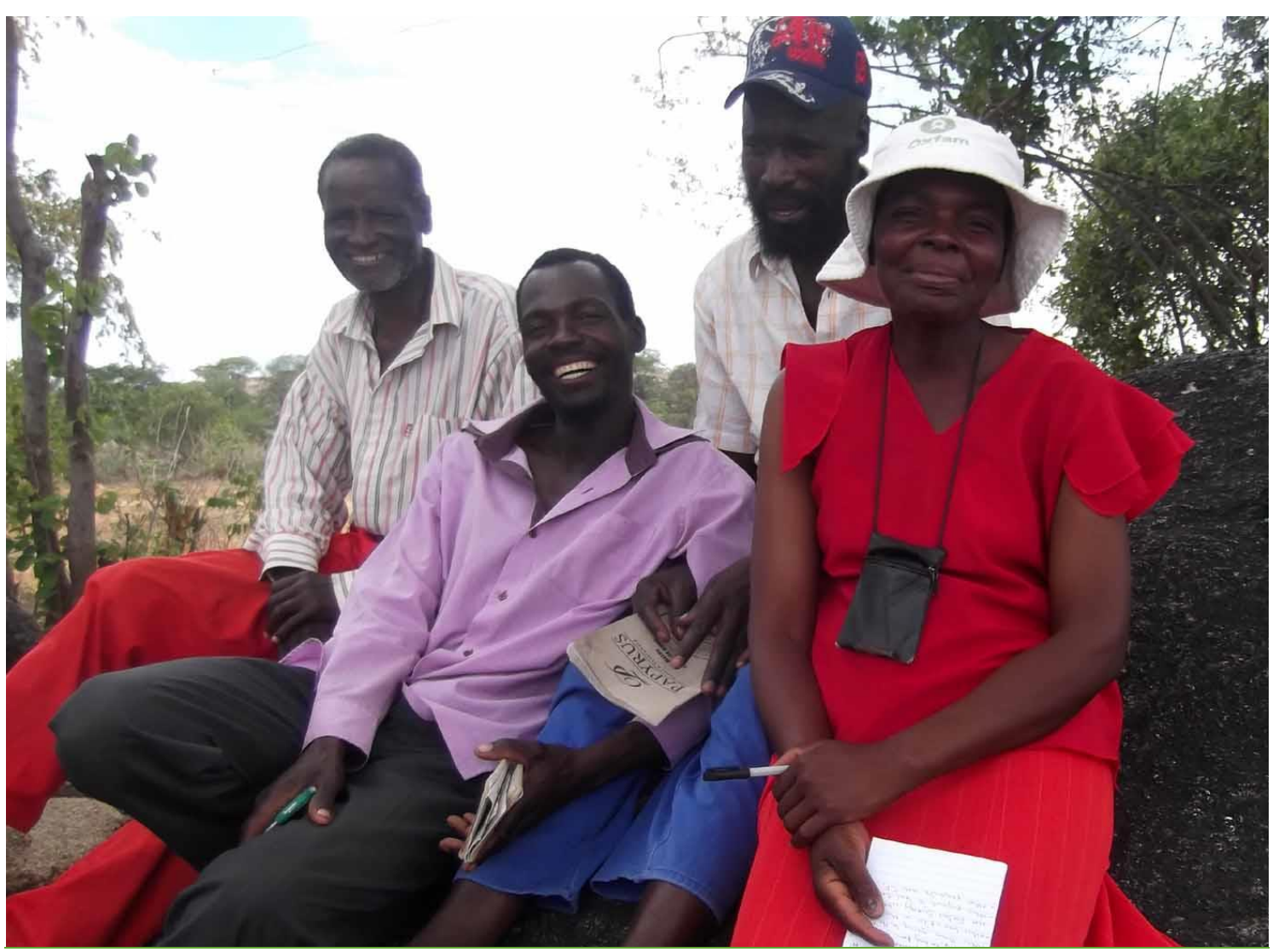

Farmers at Ruti irrigation scheme, Gutu District, Masvingo Province (from left to right: Elastos Manyanga, Katinos Mudadi, Davison Chara, and Ipaishe Masvingise). Photo: Martin Walsh/Oxfam, December 2013

\section{MARTIN WALSH}

RESEARCH TEAM, OXFAM GB

SOLOMON MOMBESHORA

WOMEN'S UNIVERSITY IN AFRICA, ZIMBABWE 


\section{SUMMARY}

Climate change is placing increasing stress on the livelihoods of people living in the world's drylands. Smallholder irrigation has long been seen as a means to improving food security in areas with unpredictable rainfall, and is now being promoted as a component in adaptation strategies. The Ruti Irrigation Project in Zimbabwe was begun by Oxfam in 2009 with these and other objectives in mind. A quantitative evaluation of the project in 2011 found that the scheme had already had significant positive impacts on household agricultural production and asset ownership. There was also some evidence for increased food security in participating households, though this was not as apparent as it might have been.

A follow-up study was commissioned in 2014 to provide a deeper understanding of these results and their wider ramifications, and its findings are presented here. It shows that the irrigation scheme has had much more significant social and economic impacts than those measured by the quantitative study, and that these have spread through the community to the households of participants' relatives, neighbours and friends.

However, these positive impacts for wellbeing have not been as extensive as originally hoped and they have been periodically curtailed by the negative consequences of extreme weather events, including the drying of the Ruti reservoir in 2013 and the decision to reserve its scarce water for use by sugar estates further downstream.

This suggests that while smallholder irrigation schemes can provide important local benefits, these are threatened not only by the usual difficulties associated with their implementation, but also by the greater challenges posed by climate change and the resource conflicts that are being exacerbated as a result. There is no simple local solution to these problems, which require significant changes in policy and practice at catchment-wide, national, and international levels. This is beyond the scope of a single project, but consistent with Oxfam's approach to tackling global inequality and climate change, which incorporates lessons learned from in-depth research of the kind reported here. 


\section{CONTENTS}

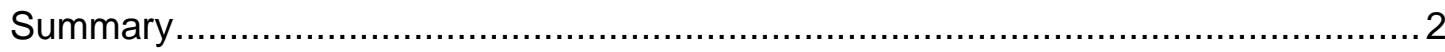

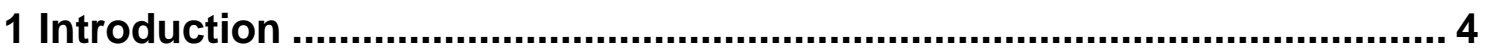

2 Process: the project in Zimbabwe and its evaluation ............................. 5

The Effectiveness Review of the Ruti irrigation project ....................................... 5

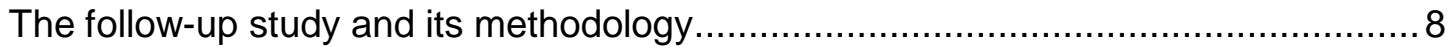

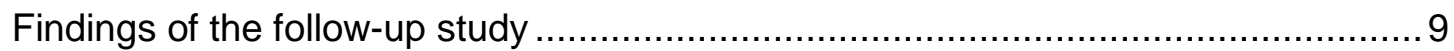

The impact on people's lives and wellbeing ................................................ 9

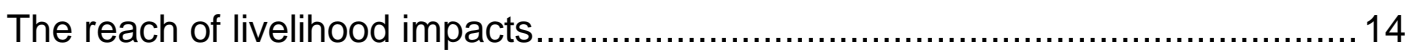

Institutional and environmental constraints .................................................... 16

3 Discussion: lessons for programmes and their evaluation..................... 18

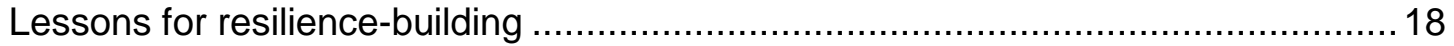

Lessons for research and evaluation ................................................................. 19

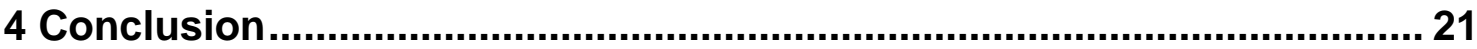

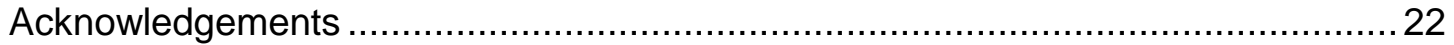

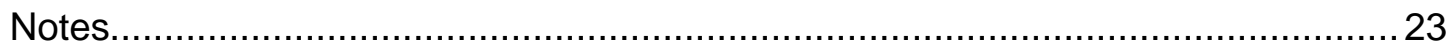




\section{INTRODUCTION}

It is widely recognized that one of the most effective ways to improve rural livelihoods, including the lives of women and children, is to provide support to the development of smallholder agriculture. There is much less agreement, however, on how this can best be done. Although this is a subject that has been much researched and written about, there is a lack of good comparative data on the specific impacts of different approaches to supporting smallholders, and in particular the most vulnerable groups of farmers. This reflects a more general problem in the practice of international development, where the value of evidence-informed policy and programme making is acknowledged, but the relevant systematic evidence is more often than not lacking. This lack of evidence is especially critical in the context of climate change, where bridging the gap between theories of practice and solutions that work is a more urgent task than ever.

Building on its long experience of humanitarian and development programming, Oxfam GB is now seeking to generate more systematic knowledge for these purposes. Since 2011 it has undertaken intensive evaluations (referred to as Effectiveness Reviews) of a representative sample of its projects worldwide. These are randomly sampled in seven thematic areas, four of which are readily amenable to study using quantitative methods and statistical analysis. ${ }^{1}$ The first quantitative reviews, using a quasi-experimental survey design, were published to much acclaim. ${ }^{2}$ At the same time it was recognized that some of their results required further elucidation, and so it was agreed that two or more qualitative follow-up studies would be undertaken on a pilot basis in order to deepen the analysis already provided by selected Effectiveness Reviews. The second to be selected for this kind of 'drill down' was the review of the Ruti Irrigation Project in Zimbabwe, and it is the outcome of this that is reported here. ${ }^{3}$

The combined study is, in effect, a mixed-methods evaluation. As well as discussing the wider implications of its results for livelihoods and resilience programming in Zimbabwe and beyond, this report also reflects critically on the process of evaluation itself, and how this might be improved. Although its conclusions are preliminary, it is hoped that this will stimulate discussion and debate, as well as help to prepare the ground for further studies of this kind. 


\section{PROCESS: THE PROJECT IN ZIMBABWE AND ITS EVALUATION}

The three-year Ruti Irrigation Project, designed to develop a scheme proposed by the Government of Zimbabwe, was funded by Oxfam under its Top Projects/Supporter Marketing initiative and began work in May 2009. ${ }^{4}$ In 2011, the project was randomly selected for an Effectiveness Review under the Livelihood Support thematic area, and field research for this was undertaken in October 2011 while the project was still running. ${ }^{5}$ The project came to its scheduled end in March 2012, and the following month an End of Project Evaluation was completed, undertaken by the Oxfam Zimbabwe MEL (monitoring, evaluation, and learning) team. ${ }^{6}$ Since then, the irrigation scheme established by the project has continued to function, though its operation was interrupted at different times in 2013 and 2014 by the consequences of two extreme weather events, which are discussed in greater detail below. Fieldwork for this follow-up study was undertaken in March-April 2014, following the second of these events (see Box 1).

\section{Box 1: Timeline}

- May 2009: start of the 3-year Ruti Irrigation Project

- October 2011: Effectiveness Review research undertaken based on quasiexperimental survey design (results published in January 2012)

- March 2012: end of the Ruti Irrigation Project, followed by End of Project Evaluation (in April 2012)

- August-November 2013: no irrigation because of low reservoir level and diversion of remaining water to sugar estates

- January 2014: flooding following heavy rainfall at the end of 2013

- March-April 2014: follow-up study undertaken in Zimbabwe (consultant's report finalized in May 2014)

\section{THE EFFECTIVENESS REVIEW OF THE RUTI IRRIGATION PROJECT}

The Effectiveness Review involved almost all of the direct beneficiaries of the Ruti Irrigation Project. The project aimed to contribute to sustainable livelihoods and resilience to climate change among poor and vulnerable households in the drylands of Zimbabwe's Gutu District. It did this through the establishment of a 60 -hectare surface irrigation scheme in which 270 farmers, many of them women, were directly supported to cultivate individual plots of land. Farmers were also given start-up seeds, tools, fertilizers and pesticides, and complementary training was provided on improved farming methods, agri-business and marketing skills and soil conservation techniques. It was hoped that the resulting year-round harvesting of crops would also indirectly benefit up to 50,000 people in the surrounding wards by providing them with a more diverse and secure source of food. 
Figure 1: Map showing location of Ruti Irrigation Project, Gutu District, Masvingo Province, Zimbabwe

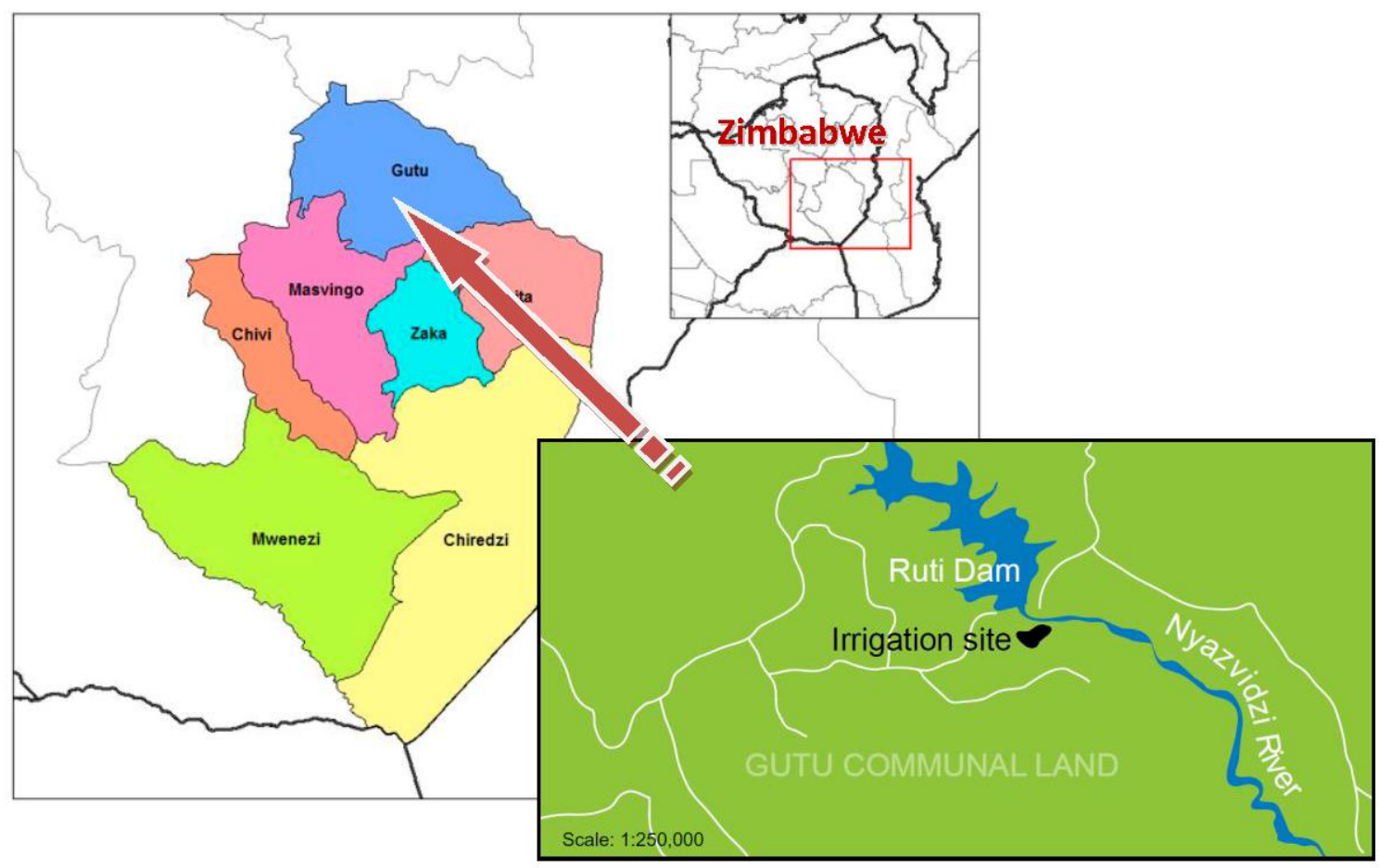

Source: End of Project Evaluation ${ }^{7}$

The project was implemented in three phases as the land was cleared, prepared for cultivation and irrigated, with more than 80 farmers in each phase. Phase 1 began in 2009, with the first group of farmers able to sow maize in 2010 and harvest it in 2011. By September 2011 these farmers were harvesting their second crop, of wheat. Phase 2 farmers had also begun to sow maize at this time, while Phase 3 farmers were beginning to clear and prepare their plots for irrigation. Different crops were planted at different times by farmers in the three phases; in some cases they were able to harvest three different crops in the same year (see Figure 2 for an overview).

Figure 2: Principal crops grown by farmers in different phases of the project, 2010-13

\begin{tabular}{|c|c|c|c|}
\hline Year & $\begin{array}{l}\text { Phase } 1 \\
n=81\end{array}$ & $\begin{array}{l}\text { Phase } 2 \\
n=93\end{array}$ & $\begin{array}{l}\text { Phase } 3 \\
n=96\end{array}$ \\
\hline 2010-11 & maize & & \\
\hline 2011 & wheat & & \\
\hline 2011-12 & maize & maize & \\
\hline 2012 & & sugar beans & \\
\hline 2012 & sugar beans & maize & \\
\hline 2012-13 & potatoes & & maize \\
\hline 2013 & sugar beans & sugar beans & \\
\hline 2013 & & wheat & \\
\hline 2013-14 & (no irrigation & t to November) & \\
\hline
\end{tabular}

Source: Ruti Irrigation Project records 
To assess the effectiveness of the irrigation scheme and agricultural support provided by the project, the Effectiveness Review employed a quasi-experimental impact evaluation design. A household survey was administered to 232 beneficiary farmers from the three phases of the project. Phase 1 beneficiaries were defined as the intervention group, having already harvested crops from the irrigation scheme. Phase 2 and Phase 3 beneficiaries, on the other hand, were defined as the comparison group on the grounds that they were yet to harvest crops on the scheme. Propensity score matching and multivariable regression were subsequently used in the statistical analysis of the survey data to reduce bias in the comparisons made between the two groups.

The survey comprised questions relating to the project's intended outcomes, including agricultural production, household consumption and asset ownership. Because the project also included a health and hygiene training component, and measures to improve water sources and latrines at the scheme, questions were also asked about water and sanitation behaviour.

Analysis then focused on teasing out statistically significant differences between the two groups of households: those that had been subject to programme interventions, and those that had not participated in or been directly affected by the programme.

The results of this Effectiveness Review were published in January 2012. It found that between eight and 10 percent more of the intervention households were living above GB£1 per day per capita compared with the comparison households. In addition, the former exhibited a greater increase in asset ownership and reported being in a better position to meet household needs. The intervention households were also found to be more food secure than those in the comparison group. These changes were most likely driven by an average increase in maize production of 240 percent for the intervention households between 2009 and 2011 . On the other hand, the survey results showed no significant behavioural differences between the intervention and comparison households in relation to the type of toilet facility that they used. A similar picture emerged for household water use, with only very small differences observed between the intervention and comparison households. ${ }^{8}$

\section{Figure 3: The traffic light symbols in this diagram provide a quick overview of the results of the Effectiveness Review}

\begin{tabular}{|c|c|c|}
\hline Outcome & Rating & Commentary \\
\hline $\begin{array}{l}\text { Outcome } 1 \text { - Greater } \\
\text { household income (global } \\
\text { outcome indicator) }\end{array}$ & & Some evidence of modest increases in household expenditure. \\
\hline $\begin{array}{l}\text { Outcome } 2 \text { - Increased } \\
\text { household asset } \\
\text { ownership }\end{array}$ & & $\begin{array}{l}\text { Strong evidence of impact in household asset change since the start of } \\
\text { the project. }\end{array}$ \\
\hline $\begin{array}{l}\text { Outcome } 3 \text { - Improved } \\
\text { food security }\end{array}$ & & $\begin{array}{l}\text { Some evidence to suggest that the intervention households are more } \\
\text { food secure than the comparison households. }\end{array}$ \\
\hline $\begin{array}{l}\text { Outcome } 4 \text { - Increased } \\
\text { agricultural production }\end{array}$ & & $\begin{array}{l}\text { Strong evidence of significant increases in maize production among the } \\
\text { intervention households. }\end{array}$ \\
\hline $\begin{array}{l}\text { Outcome } 5 \text { - Improved } \\
\text { water and sanitation } \\
\text { behaviour }\end{array}$ & & $\begin{array}{l}\text { Evidence of very small impact in relation to changing the type of water } \\
\text { source used by the household. }\end{array}$ \\
\hline
\end{tabular}

Source: Effectiveness Review snapshot ${ }^{9}$ 


\section{THE FOLLOW-UP STUDY AND ITS METHODOLOGY}

While the effects of the project on water and sanitation behaviour appeared to be negligible, its impacts on agricultural production and a number of livelihood outcomes were quite positive, if not as strong as project planners might have wished. In addition to making recommendations about the need to support crop marketing and strengthen the health and hygiene training component of the project, the Effectiveness Review made the following suggestions for further research into the impacts of increased production on the irrigation scheme:

- Consider further research to assess the food security impact of the project on the wider community: As the project matures, it will be interesting to assess how it has impacted wider communities in relation to food security. Within the project logic model there are explicit objectives regarding improving food security conditions for approximately 50,000 households in the wider surrounding areas of the project. It is suggested that the project team considers a similar evaluative approach as in this effectiveness review with neighbouring communities to assess wider impact.

- Follow-up on some of the specific findings from this report with further qualitative research: Specific qualitative research which may help to explain why the large change in asset ownership between 2009 and the present in the intervention group is not mirrored by large changes in consumption and expenditure would be beneficial to this analysis. Also, it would be interesting to find out how the surplus maize produced in the first harvest by Phase 1 (intervention) farmers was specifically used (e.g. storage, provision to family/neighbours, sold at market etc) in the absence of supporting marketing interventions. ${ }^{10}$

In order to answer these and other questions arising from the Effectiveness Review, the Ruti Irrigation Project was selected as the subject of Oxfam GB's second in-depth follow-up study. ${ }^{11}$ Following a scoping visit to Ruti by Oxfam researchers (including the first author of this report) in December 2013, it was decided that the study should include both quantitative and qualitative components. Oxfam's Senior Regional Research Adviser in Pretoria led a review of data from the project and other available sources in order to estimate the potential impact of increased agricultural production on the wider population of the project area. This resulted in a reworking of the analysis in the End of Project Evaluation.

Meanwhile, in February 2014 a Zimbabwean anthropologist and development consultant (the second author of this report) was commissioned to undertake field research, and was asked to answer the following questions.

\section{How did the Ruti irrigation scheme impact upon (a) the households of scheme members, and (b) other households in the wider community?}

1.1 What impact did the production, consumption and disposal of irrigated crops have on gender relations in different participating and non-participating households? What impacts were there on women's empowerment, decision making, labour, and the role of children? How did these impacts come about?

1.2 What impact did the production, consumption and disposal of irrigated crops have on livelihoods in different participating and non-participating households? What impacts were there on incomes, assets, and other components of livelihoods? How did these impacts come about?

1.3 What impact did the production, consumption and disposal of irrigated crops have on food security in different participating and non-participating households? How did these impacts come about? 
How widely did these impacts spread? How did they spread, and what stopped them from spreading further?

\section{What factors explain variation in impacts (e.g. between households) and the absence of some impacts?}

Fieldwork was undertaken in Gutu and Buhera Districts in Zimbabwe in March-April 2014 by the consultant and an assistant researcher, facilitated by Oxfam staff. While the irrigation scheme and its farmers are located in Wards 13 and 14 of Gutu District, the impacts of the project have been felt much further afield; hence the decision to also undertake research in the neighbouring district of Buhera, across the Nyazvidzi River (see Figure 1). Research used the following methods:

- Literature review (of project documents and other sources relevant to understanding the irrigation scheme and its impacts, including production data and evaluation findings);

- Key informant interviews (with district and government department officials and others involved in the development and administration of the scheme);

- Focus group discussions (three with men and women farmers from different phases of the scheme; one with farmers who were not members of the scheme);

- Semi-structured interviews (with a purposive sample of household members in and outside of the scheme, including scheme members who joined in different phases, and men and women in different kinds of household, interviewed separately as appropriate)

In total, 22 irrigators (17 men and 5 women) and 11 non-irrigators ( 8 men and 3 women) were interviewed. At the start of each interview they were asked to outline their life histories, before describing the variety of impacts the scheme had on them and their households. Quantitative data on household demographic and socio-economic characteristics were also recorded. Interviewees were also asked about decision making and the changing nature of gender relations in the household, the role of children, and the impact of external events on livelihoods and farming on and off the scheme. ${ }^{12}$

The external events included extreme weather events. As the timeline (Box 1) indicates, the Ruti irrigation scheme suffered from the effects of a serious drought in August-November 2013, followed by heavy flooding in January 2014. In order to understand the impact of these events in greater depth, further research on this subject was undertaken by Oxfam staff in FebruaryMarch 2014, and the results formed an additional input to the follow-up study. ${ }^{13}$

\section{FINDINGS OF THE FOLLOW-UP STUDY}

The rest of this report is based primarily on a distillation and reanalysis of the consultant's report and other pieces of research outlined above, with reference back to the results of the Effectiveness Review and the End of Project Evaluation.

\section{The impact on people's lives and wellbeing}

The Effectiveness Review indicated that Phase 1 farmers more than tripled their production of maize in the first season of irrigated production in 2010-11. Their average production per household increased from $261 \mathrm{~kg}$ in 2009 to $886 \mathrm{~kg}$ in 2011 , whereas it decreased from $189 \mathrm{~kg}$ to $146 \mathrm{~kg}$ on average in the comparison group of Phase 2 and 3 farmers. ${ }^{14}$ Comparable increases in maize production were reported in the End of Project Evaluation, which compared baseline data from 2009-10 with survey results from $2011-12 .{ }^{15}$ The same study found that whereas very poor households were producing 43 percent of their own annual food needs at baseline, by 
project end this had risen to 95 percent (and from similarly low levels to more than 60 percent in less vulnerable households). ${ }^{16}$

Figure 4: Decision tree showing the multiple possible uses of crops harvested from the Ruti Irrigation scheme

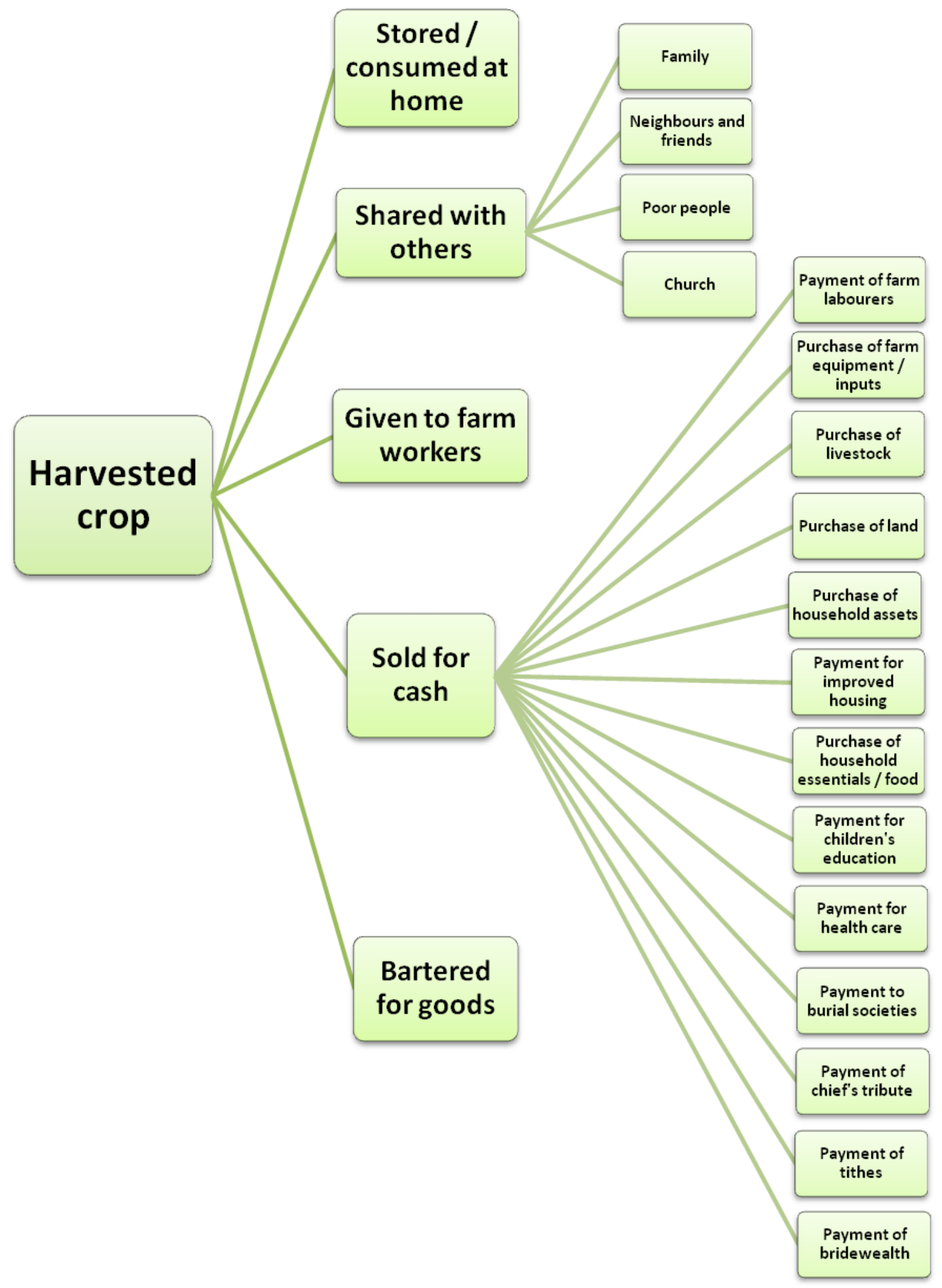

Source: Mombeshora $(2014)^{17}$ 
The follow-up study confirmed that these and other increases in crop production had significant impacts on food security. 'Before the scheme was established many people in the area were struggling to make ends meet, but now they are food secure', said one 42-year-old single mother. ${ }^{18}$ Most interviewees agreed that food had become more readily available and accessible, as a result of which dietary diversity and nutrition had improved, a conclusion supported by data collected for the End of Project Evaluation. ${ }^{19}$ The production of wheat, sugar beans and other crops on the irrigation scheme also meant that the farmers had produce available for sale and other forms of exchange. Figure 4 illustrates graphically all the different ways in which farmers were able to use their harvests of irrigated crops.

Figure 5: An example of one woman's use of a sugar bean harvest

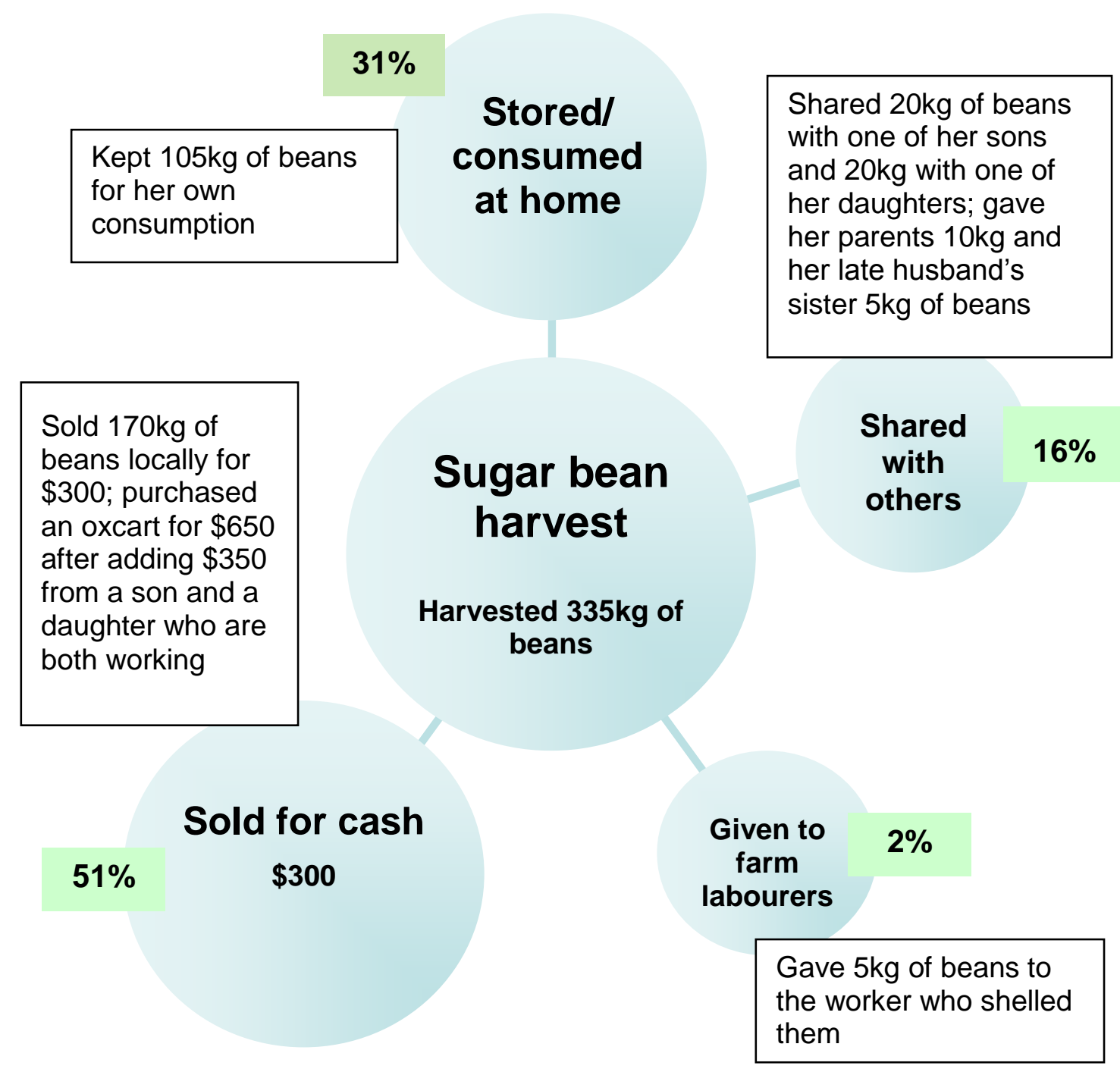

How a 49-year-old widow used her 2011 sugar bean harvest

Source: Mombeshora $(2014)^{20}$ 
Figure 5 gives one specific example. It is important to note here that there was considerable variation in the uses of harvests, not only between farmers and from one kind of crop to another, but also from one season to the next. In 2013, the same woman harvested a total of $240 \mathrm{~kg}$ of sugar beans, of which she sold $80 \mathrm{~kg}$, using the money to pay for examination fees for her son and also to buy 10 broiler chicks and stock feed (she ate the grown chickens the next Christmas). She gave $5 \mathrm{~kg}$ of beans to her son, and $5 \mathrm{~kg}$ to her daughter, and kept the remaining $150 \mathrm{~kg}$ for her own consumption and use as a reserve in case she needed to raise money to meet domestic expenses. These and other narrative accounts that were recorded during the follow-up study were not comprehensive enough to permit systematic quantitative analysis of the patterns of utilization and the reasons for them, but they clearly show farmers responding to the demands and opportunities facing them at different points in time. The advent of the irrigation scheme evidently provided most participants with many more options than they had enjoyed previously.

The everyday consequences of this are best expressed in the words of the farmers themselves, comparing life before and after they had joined the Ruti scheme. As one single mother enthused, 'Life after the scheme became rosy and we ululated when the scheme idea was mooted. ${ }^{21}$ The examples given in Box 2 are fairly representative of 'before' and 'after' statements.

\section{Box 2: Farming before and after joining the irrigation scheme}

\section{Before:}

'Life was very difficult before we joined the irrigation scheme. We had nothing to eat and all we did was to wake up and look for food. We could do anything to get food including working on farms as casual labourers in order to raise money to buy food for the family. We grew a variety of dryland crops before the irrigation scheme and they did not do well considering the fact that our area is the driest in Gutu District and is characterized by low rainfall patterns and high temperatures. We survived on eating wild fruits that we shared with wild animals such as baboons. Crops grown before the scheme were pearl and finger millet, sorghum, groundnuts, and sunflowers. What we harvested could not even last four months and the rest of the months till the next harvests we were always struggling to get food.'

Phase 1 farmer, a single mother of 48 years

\section{After:}

'When we joined the scheme, life immediately changed for the better and we were able to get maize in abundance and our health also improved. We were then able to pay school fees, buy books for our children and money for milling. We stocked the maize in granaries and did not sell. In 2012, I sent 3 bags of wheat to GMB [the Grain Marketing Board] [...]. We got our payments of $\$ 66$ each after a year and used the money to pay ZINWA [Zimbabwe National Water Authority] bills [...]. We prioritized these because without paying for water one is then disconnected [...]. Maize for 2011 was reserved for domestic consumption while beans were sold locally at a shop [...] selling at $\$ 40$ per $20 \mathrm{~kg}$ bucket. I only sold one $50 \mathrm{~kg}$ bag for $\$ 120$ and reserved 1 bag for domestic use. The money realized from the sale of beans was used to buy inputs such as fertilizers and pesticides. We also gave relatives in Buhera some maize.'

Phase 1 farmer, a married woman of 54 years

Source: farmers interviewed in March 2014, quoted in Mombeshora (2014) 22 
Joining the irrigation scheme was transformative for many farm households, especially those who joined it in the first two phases. The project gave priority to vulnerable women, and its impact on the lives and wellbeing of some women and girls is particularly marked. The Ruti farmers' most eloquent spokesperson in this regard has been Ipaishe Masvingise, a widow who was 49-years-old at the time of our study. ${ }^{23}$ Ipaishe was the treasurer of the first Ruti Irrigation Management Committee, has worked as a community educator for Oxfam and other organizations, and was chosen to deliver a 1.3 million signature petition to President Francois Hollande at the start of the COP21 UN climate negotiations in Paris in December 2015. ${ }^{24}$ This is what she told us in March 2014:

'The scheme has also empowered us widows and it has removed the stigma attached to single mothers and widows regarding ownership of land. Women are now proud owners of land in the area, land which they call theirs. This is something that was unheard of in the past. Unlike in the dryland areas where women have access to land through their husbands, women in the irrigation scheme own their land and this land can be put in the will and it can be inherited by heirs of their choice. ${ }^{25}$

This means that widows and single mothers who only have daughters can pass on the land to them. There is also anecdotal evidence to suggest that married women have been empowered by participation in the scheme, at least to the extent that decisions about irrigated crops and their utilization are made jointly by the majority of married couples with irrigated plots.

\section{Box 3: Impacts on marital harmony}

'There is now love between husbands and wives because children are now able to go to school. We used to quarrel a lot, urging husbands to go and look for work. Now we plan things together.'

Woman farmer, participating in a focus group discussion

'After joining the irrigation scheme, there is no more hunger and there is growing love in the family. We can now work together in the scheme, accompany each other to the scheme during the night to irrigate our crops. Work is now easy because we are now working together.'

Phase 2 farmer, married man of 51 years

'Love is now thriving in the house because we now have plenty of food in it. We managed to buy cement for our kitchen which is under threat of waterlogging. [...] Women have also been empowered by the scheme as they are now able to buy domestic appliances such as pots and plates.'

Phase 2 farmer, woman of 34 years

Source: farmers recorded/interviewed in March 2014, quoted in Mombeshora (2014) ${ }^{26}$

The most striking indications of this, linguistically at least, were statements to the effect that 'love' had increased in some of the households concerned (see Box 3 ). This has also made it easier for some women to engage in social and economic activities outside of the household, such as participation in rotating savings and credit associations with other women irrigators. Women's representation on the Ruti Irrigation Management Committees, including in leadership roles, is also much greater than has traditionally been the case in local institutions, though women are still in the minority. Ipaishe Masvingise is an outstanding example of a woman who has blossomed in this context. 


\section{The reach of livelihood impacts}

The irrigation scheme has clearly had the potential to bring about significant changes to the lives of participating farmers and the wellbeing of their households. But how far do these impacts reach? As noted earlier, it was hoped that year-round harvesting of crops at Ruti would indirectly benefit up to 50,000 people in the surrounding wards by providing them with a more diverse and secure source of food. The Effectiveness Review did not attempt to assess these wider impacts, but suggested that further research be undertaken to do so. This was therefore one of the tasks of the follow-up study, and the reason that it included research among nonirrigators both in Gutu District and across the Nyazvidzi River in Buhera District (see Figure 1).

A number of the Ruti farmers we interviewed said that whereas they had often had to rely on help from others before they joined the scheme, afterwards they were in a much better position to provide that help themselves. They did this in particular by sharing surplus food with neighbours, friends and relatives. In this and other ways they had become net givers of mutual aid rather than recipients. An example is given in Box 4 of a farmer in Ward 14 who counted this among the principal benefits of irrigated cultivation.

\section{Box 4: Sharing food with friends and relatives beyond the irrigation scheme}

'Life changed drastically after I joined the scheme. What we could not get in dryland farming we could now produce in the scheme. We could now stock extra food in granaries, a thing that was unheard of before the scheme. We used to keep food in sacks in our huts. We could now share food with our relatives and friends who are not in the scheme. I gave food to my sister who is married in Murwira area in Buhera. I gave her 200kg of maize. I gave my daughter who is also married in Buhera under Chief Bangure some 60kg of maize. I also gave my neighbour [...] 40kg of maize after my harvest in the scheme. I also gave my brother-in-law [...] 40kg of maize. My brother-in-law stays in Ward 13 under Chief Mazuru. I have occasionally assisted him with my oxcart and two oxen which he currently has. I ask for nothing in return since they are my relatives and some of them assist me during planting, weeding, harvesting and spraying of chemicals.'

Phase 1 farmer, a married man of 56 years

Source: Mombeshora $(2014)^{27}$

Non-irrigators confirmed that they had benefited from the scheme in different ways: through gifts of food, from the greater availability of food for sale in the community, and from the employment opportunities that the scheme provides. Many dryland farmers in the surrounding area work as casual labourers on the scheme, and they are often paid in kind (as shown in Figure 4, and the example in Figure 5). The individual impacts of this are illustrated in Box 5 by a farmer in Ward 13. 
When the scheme started we also provided labour in the scheme and we got paid $\$ 8$ per day for the work we did. The work included laying pipes and other general duties assigned to us by our superiors. I submitted my name but could not get a plot in the scheme. We were told that we will be considered when other phases are complete.

[...] I am a dry land farmer who survives on part-time work. [...] I produce very little and the yields can only last me for three months. I start looking for food around September every year. [...] I supplement the poor harvests by working in the scheme for people I trust and know. [...] The work that I do in the scheme includes de-stumping, ploughing, weeding, planting, harvesting and transporting the harvest to plot holders' houses. I also irrigate their crops during the night since some of them are widows and single mothers and they are afraid to travel to the scheme alone during the night. The distance to the scheme by foot is approximately two hours' walk and cycling takes about one hour to get to the scheme. In a busy month I can realize $\$ 50$ and in a bad month I can pocket at least $\$ 25$.

I bought five chickens from the money realized in the scheme in 2011 and they have now multiplied to 15. I also ate some along the way. Apart from the money that I get from the scheme I also get sugar beans, wheat and tomatoes from plot holders to give my family. Sometimes I borrow food from them and do some work for them in return. Now I can safely say I am food secure due to the scheme. I am also benefitting from the scheme members because they give me advice and inputs such as seeds for free. [...] Sometimes when I work in the scheme I get three buckets of wheat, beans and maize per day. In 2012 I had to sell 12 bags of maize that I worked for in the scheme and I used the money to pay part of my lobola [bridewealth] which was outstanding. [...] The money that I work for in the scheme I use it to pay school fees for my children, buy uniforms and pay tribute to the chief. We pay $\$ 1$ every month towards chiefs and headman allowances. I also use the money to buy groceries and I am currently raising money to buy asbestos and cement so that I can build a three-bedroom house.'

Non-irrigator, a married man of 42 years

Source: Mombeshora $(2014)^{28}$

Although a minority of farmers without plots on the scheme said that they had benefitted relatively little from it, they all expressed a desire to join it. It should be noted, however, that our interviewees were all within what might be called the immediate catchment of the scheme: we would not expect to hear the same benefits reported at increasing distances from it.

It is difficult to quantify the wider impacts of the scheme on the basis of the relatively small number of anecdotal accounts that we collected, though possible to envisage ways in which this might be done more systematically. In the absence of more detailed information of this kind, we are obliged to resort to proxy measures. The End of Project Evaluation that was conducted in Wards 13 and 14 in 2012 used available crop production data and estimates of household food needs to estimate that the scheme had 'the potential to provide sufficient annual food requirements (in cereal equivalent) for approximately 3000 people (that is 20 percent of the population) in the two wards assuming that two crops are grown in one calendar year and all three phases are operational. ${ }^{29}$ Similar calculations made for the follow-up study in 2014 produced an even lower estimate of 2,080 people who might be fed by the scheme. Of these 1,134 were notionally members of the irrigators' own households and the remaining 946 people in other households in the area.

It should be emphasized that these are very rough estimates of direct benefits that do not take into account other productive household activities as well as other direct and indirect benefits from the scheme. They are well short of the numbers envisaged by project planners when they 15 Turning Water into Wellbeing: How an irrigation scheme changed lives in a Zimbabwean dryland 
predicted that the scheme would have up to 50,000 indirect beneficiaries. This was perhaps an over-optimistic forecast, though much depends on the definition of indirect benefits and the time-frame in which they are measured. The real reach and significance of the irrigation scheme 's impacts most likely lies somewhere between these extremes, though we will not know for certain unless a more robust methodology can be employed. ${ }^{30}$

\section{Institutional and environmental constraints}

Since its beginning, the irrigation scheme has faced a number of constraints, and these have prevented it from reaching its full potential. The End of Project Evaluation highlighted the difficulty that many farmers on the scheme experienced when trying to market their crops and this problem was mentioned in many of the interviews for the follow-up study. ${ }^{31}$ Markets for agricultural produce are not well developed in Wards 13 and 14 in Gutu District, and this is exacerbated by the poor condition of the roads leading to the scheme. Surplus food crops are sold directly to other households more often than they are taken to local markets and shops. Some irrigators have sold crops to the government-controlled Grain Marketing Board (GMB), but like farmers elsewhere in Zimbabwe, have been disappointed both by long waits for payment and the small sums then given. Here is one man complaining about this:

In 2010, we harvested $840 \mathrm{~kg}$ of wheat. We used $640 \mathrm{~kg}$ for own consumption after selling $200 \mathrm{~kg}$ of wheat to the GMB. The GMB was reported to have deceived the farmers because we did not get anything meaningful from the sale of wheat. The GMB told farmers to pool their wheat and deliver it to the nearest depot in Gutu. It took more than six months for the GMB to pay the farmers. Efforts by the farmers to go to the GMB to try and secure early payments were fruitless. I made a big loss; for the 200kg delivered I only got \$62. 32

At least in cases like this, farmers have been able to switch to domestic consumption and local networks of exchange. But this has discouraged the cultivation of crops for sale, and wheat, for example, has not been planted in such quantities again.

While controlled irrigation removes much of the day-to-day uncertainty that affects dryland farming, it is still vulnerable to large-scale environmental shocks and the decisions taken in relation to these. After the end of the Oxfam-funded project in March 2012, the irrigation scheme was negatively affected by a succession of extreme weather-related events, the results of prolonged drought followed up by severe flooding, as detailed in Box 4 .

\section{Box 6: Weather extremes and their consequences for the irrigation scheme in 2013-14}

[T] he irrigation scheme ran into problems in 2013. The 2011-2012 rains came late and then there was a mid-season dry spell that lasted for seven weeks. The 2012-2013 rains were poor then it did not rain all year until the very end of 2013.

By mid-2013 the level of the lake had fallen dramatically. The water pressure was so low that only a trickle of water was flowing to the farmers' plots. Then the problem for the irrigation scheme participants was made even more acute when the Zimbabwe National Water Authority (ZINWA) decided to allocate the available water to sugar estates in Chipinge District, Manicaland Province.

Farmer Mr Savious Murikitiko said: "The dam dried by September 2013. That's an entire cropping season lost. From as early as July through to December last year we could do nothing."

The combination of low water pressure, allocation decisions and late rains meant farmers at Ruti harvested their first crop but their second crop was poor and their third crop "a complete write-off". 
The farmers had depended on selling their first crop to pay for the inputs for the second, and so on, so the situation became progressively worse. They seemed, they said, to be back to square one - indeed, some said they were even worse off than dryland farmers.

Then after the drought came extraordinarily intense rains. The water levels behind Ruti dam rose so fast that the water exploded over the spillway one day in January. Fishermen collecting fish below the spillway had to flee for their lives; 10 of them had to be rescued by government helicopters. Furthermore, the flood waters tumbled boulders against the irrigation pipeline, cracking it. Water has been shooting out, thus reducing the water pressure in the pipeline, which could affect cropping prospects for 2014 unless it can be repaired.'

Source: Magrath (2014) $)^{33}$

The Effectiveness Review and End of Project Evaluation predated these events, but they are amply reflected in the accounts of the farmers interviewed for the follow-up study in March-April 2014. All of the participants and stakeholders in the scheme were affected by the lack of irrigation and failure of crops in 2013, particularly Phase 3 farmers who had yet to fully establish themselves. ${ }^{34}$ Figure 6 shows the impact on the total production of the three main crops on the scheme. The declines in maize and sugar beans in 2012-13 were attributed to the extreme weather events, while the earlier fall in the production of wheat was a consequence of the marketing problems that have already been described.

Figure 6: Total production of maize, beans and wheat by year, 2010-2013

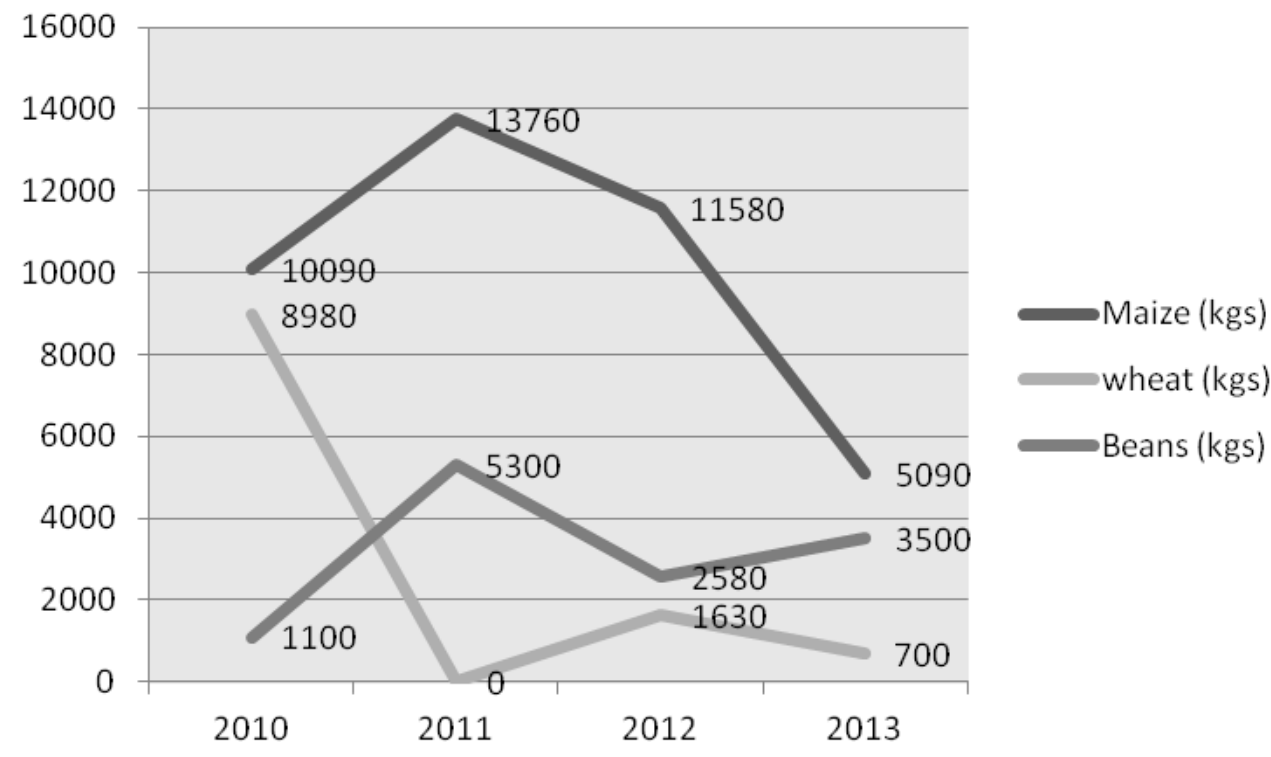

Source: Mombeshora (2014) $)^{35}$

The problems on the irrigation scheme were not caused by weather events alone, but by the water authority's response to one problem (falling water levels), and lack of response to another (the damaged water pipe; not the first time this had happened). ${ }^{36}$ The decision to allocate scarce water resources to the sugar estates in the Middle Sabi Valley in Manicaland Province reflects the greater economic importance of sugar production, both for the employment it provides and the foreign exchange it generates. ${ }^{37}$ Happily, the Ruti reservoir filled up in 2014 and the pipe feeding the irrigation scheme was fixed. The government signalled its recognition of the value of the scheme by giving two tractors to the management committee in 2015; they had to be paid for, but in the meantime, could be hired out both on and off the scheme. When reservoir levels fell again during the El Niño-caused drought of $2015-16,{ }^{38}$ the irrigation scheme continued to receive water, and in March 2016 all three phases of the scheme were reported to be operational and working well. At the same time the off-take to the sugar estates was said to be experiencing problems of its own, with water being lost and evaporating. ${ }^{39}$ 


\section{DISCUSSION: LESSONS FOR PROGRAMMES AND THEIR EVALUATION}

It should be emphasized again that we have distilled these findings from our interviews and the report of the qualitative follow-up study, which provides a lot more detail than can be given in a short overview. ${ }^{40}$ Nonetheless, we believe that these are significant findings and that a number of important lessons can be drawn from them. These are discussed below, along with some of the methodological implications of this study for future evaluations.

\section{LESSONS FOR RESILIENCE-BUILDING}

The Effectiveness Review and the End of Project Evaluation of the Ruti Irrigation Project which were undertaken independently, both showed that smallholder crop production had increased significantly on the scheme, and that this in turn had some positive impacts on irrigators' livelihoods and food security. While this is not a particularly surprising finding, qualitative research for the follow-up study has added a lot more detail, and given us a much better understanding of how and why increases in agricultural production have led to the changes that they have. We did this by asking farmers both to compare their lives before and after joining the scheme, and to tell us how they had used particular harvests, together with the income derived from the sale of crops. This in turn provided us with a series of snapshots of the forward linkages of irrigated crop production, including its wider social and economic impacts.

These narratives and the data drawn from them reveal two important aspects of the scheme's impacts:

- the multiplicity of uses to which farmers on the scheme were able to put increased agricultural production - paying for farm labour; securing household food supplies; giving to neighbours, friends and kin; selling for cash; and using this money to pay for a range of goods and services, including farm inputs, school fees, medical treatment, domestic consumables, and local taxes and tithes;

- the transformative potential of participation in the irrigation scheme, both in terms of its positive impact on livelihoods and food security, and its ability to change gender relations within and to some extent between households, by empowering women to own and inherit land on the scheme, participate in its management, and play a greater role in decision making both on the farm and at home, especially after harvest.

These impacts on gender relations have come about in part because the participation of women, and vulnerable women in particular, was targeted by the project. There is an important lesson in this, because it has meant that the scheme has had much more significant social impacts than it might otherwise have had.

As we have seen, the project was also developed with the assumption that it would have positive impacts on food security in the wider community. Our qualitative research has shown that the increased availability of food for purchase is only one of the ways in which this might be achieved. A large number of men and women farmers in the surrounding area work or have worked as casual labourers on the irrigation scheme, where they are most often paid in kind. In many cases this has had significant impacts on their own households. Meanwhile, many other people in the surrounding wards in Gutu and Buhera Districts have benefited from gifts of food from neighbours, friends and relatives with plots on the scheme. 
Needless to say, these impacts have not been felt as widely as project planners originally envisaged. In addition to an element of over-optimistic miscalculation, the principal reasons for this have been the following:

- marketing problems, caused both by the relative underdevelopment of local markets and marketing infrastructure (including poor roads), and the failure of the government-controlled Grain Marketing Board (GMB) to pay farmers either proper market rates for their crops or in a timely fashion;

- the negative effects of weather extremes, both drought and flooding, on the irrigation scheme, exacerbated by delays in maintenance and, most seriously, by poor decision making on the part of the Zimbabwe National Water Authority (ZINWA) when it shut down the supply of water to the scheme in favour of supplying the sugar estates downstream of the Ruti Dam.

The most obvious lesson to take from this is that such institutional and environmental constraints must be given full consideration in the planning and implementation of any irrigation scheme, together with measures to address them. The intensification of agricultural production and promotion of greater food security cannot be achieved by technical interventions alone, but inevitably involve questions of political economy. This includes the mounting challenge posed by anthropogenic climate change and related trade-offs as governments struggle to balance the competing interests of different claimants on scarce water resources. The growing voice of the Ruti farmers and increasing government recognition have enhanced the resilience of the scheme, helping them to come through the recent El Niño event relatively unscathed. But there will be further tests to come at Ruti and elsewhere, and these will require concerted action at global and regional as well as national and local levels.

\section{LESSONS FOR RESEARCH AND EVALUATION}

The quantitative Effectiveness Review of the Ruti Irrigation Project and its qualitative follow-up comprise in effect a mixed-methods evaluation. The first study in this series highlighted the need to integrate different kinds of evaluation, as well as quantitative and qualitative methods in impact evaluation, so that they inform each other, enhancing explanatory power and reducing cost and other resource requirements. ${ }^{41}$ Research for the Effectiveness Review and End of Project Evaluation of the Ruti Irrigation Project were undertaken independently in 2011 and 2012 respectively, and used very different quantitative methods. Field research for the follow-up study, which was based primarily on qualitative methods, took place well after the end of the project, in 2014. By this time, the farmer-managed scheme had experienced the deleterious effects of successive weather extremes, events which followed after the two earlier evaluations. The differences in their timing clearly affected the findings of each separate piece of research, and only the follow-up study was able to take account of a period of scheme implementation sufficient to reveal the significant problems that the earlier evaluations missed. Oxfam's Effectiveness Reviews are usually undertaken when projects are still underway but 'mature': this can work well, but it also carries the risk that important insights will be missed, especially where projects are designed to become self-sustaining and so last much longer than the project period. Although typically undertaken somewhat later, End of Project Evaluations suffer from the same problem.

The lack of a good qualitative understanding of the project at the time of the Effectiveness Review led to a serious methodological error. As we have seen, for the purposes of survey research, Phase 1 beneficiaries were defined as the intervention group, having already harvested crops from the irrigation scheme. Phase 2 and 3 beneficiaries, on the other hand, were defined as the comparison group on the grounds that they were yet to harvest crops on the scheme. The problem with this was that farmers selected to join Phases 2 and 3 were already benefiting from the scheme. Phase 2 farmers had received farm inputs and were 19 Turning Water into Wellbeing: How an irrigation scheme changed lives in a Zimbabwean dryland 
beginning to prepare plots and sow seeds when the quantitative survey was undertaken. Many of them, along with members of the Phase 3 cohort, were working as casual labourers for Phase 1 farmers, and as such had received portions of their first harvests. They were also in a position to benefit in other ways, as recipients of direct gifts of food, as well as from the greater availability of produce for sale. They were not therefore a valid control group, and the comparisons made with them are flawed. This undermines the results of the Effectiveness Review, which on some measures might otherwise have shown greater differences between the two groups, and so more significant project impacts. And although it would have been better if a comparison group with no direct connection to the scheme had been chosen, none of the communities in its wider catchment would have sufficed. This should have been evident as soon as the project's theory of change was examined.

There were other problems too with the Effectiveness Review, though not as serious as this. Because it was designed using the template applied to other livelihood-themed projects, it failed to examine and so capture the full range of impacts at household and other levels that it might have done, including, most notably, impacts on gender relations. Although it is easy to say this with hindsight, the project's targeting of vulnerable women should have alerted evaluators to the potential importance of these impacts. The absence of relevant questions could then have been fixed in part by importing the module on women's empowerment that is included in other Effectiveness Reviews. No attempt was made either to assess the wider impacts of the project. As well as failing to take account of these, the survey methodology was inadequate to the task of tracing them, and the Effectiveness Review's recommendations for further research make this explicit. That said, the follow-up study also failed to arrive at a good quantitative estimate of these wider impacts, not least because resources were insufficient to undertake further surveys or do little more than revisit the calculations made for the End of Project Evaluation and its Household Economy Approach (HEA).

The follow-up study did at least demonstrate the potential value of tracing the forward linkages of agricultural production and exchange on and off the irrigation scheme. The mapping of individual households' harvests and their uses was incomplete: it would have taken far too long to collect comprehensive information from all of the interviewees, even if they had been able to recall it and had the patience to do so. However, the snapshots that we did collect provided a wealth of information, and it would not be difficult to devise ways in which this could be elicited more systematically using a survey questionnaire, in order to generate data that could be analyzed statistically. This approach to tracking impacts has much wider applicability than to irrigated crops production or agriculture more generally. When undertaken qualitatively, it is also a useful method for teasing out observations that otherwise might have been missed, and in the follow-up study it complemented the narratives that were elicited when interviewees were asked to compare their lives before and after the advent of the irrigation scheme. As a result, the ethnographic and interpretive research undertaken for this study provided a much richer account of impacts at household and community level than the effectiveness review survey was able to. Ideally, these and other kinds of qualitative research, including literature review, should precede and inform the design of surveys. This would have made the impact evaluation of the Ruti irrigation project and scheme a much more efficient and effective exercise than it was. 


\section{CONCLUSION}

The principal conclusion of this mixed-methods evaluation of the Ruti Irrigation Project and the scheme it established has already been summarized in the Oxfam case study Irrigation Schemes and Weather Extremes: The challenge for Zimbabwe:

Smallholder farmers in Zimbabwe have always faced extreme weather variability, periodically throwing lives into disarray, ruining livelihoods and increasing poverty. Yet with the right kind of support, hardworking smallholder farmers can achieve remarkable increases in production, realize great improvements to their lives and become much more resilient to weather extremes.

Climate change, however, is going to bring more shocks in the shape of even greater extremes - both more frequent and serious droughts and more intense rainfall. This case study of an irrigation project implemented by Oxfam and the government of Zimbabwe in Ruti, in Gutu district of Masvingo province, indicates that local adaptation efforts can go a long way, but there is still a danger that people may lose out and their efforts be frustrated unless they are part of a wider supportive political and economic framework. ${ }^{42}$

As a result of the recurrence of droughts and floods in different parts of Zimbabwe, national policy responses have for a number of years emphasized smallholder irrigation development and the promotion of food security. ${ }^{43}$ The development of secure livelihoods and food security are also important components of Oxfam's work to tackle the root causes of poverty in Zimbabwe. ${ }^{44}$ Collaboration with government and other agencies at Ruti has demonstrated that well-run irrigation schemes can have transformative impacts upon the lives and wellbeing of dryland farmers, especially vulnerable women when they are specifically targeted as beneficiaries. Some of these benefits may also spread into the wider community, though marketing and other infrastructural constraints must be tackled if this potential is to be achieved. In the case of the Ruti scheme, initial projections of these wider impacts were far too optimistic.

Irrigation can make smallholders more resilient to weather extremes, but it does not entirely remove them from the threats posed by anthropogenic climate change, especially when they are the victims of poor decision making and trade-offs in the allocation of the scarce water and other resources on which irrigation depends. These problems were alleviated in Ruti when government recognized the comparative success and importance of the scheme. With Oxfam's help, the scheme has given local farmers a voice, and the ability to influence government. ${ }^{45}$ When Ipaishe Masvingise was catapulted onto the world stage at the COP21 in Paris, it even provided the women and other smallholders of Ruti with a global platform. This example also underscores the importance of advocacy and campaigning at global, regional and national levels to fight the challenge of climate change and address other structural constraints to poverty alleviation, the attainment of social and economic justice, and the enhancement of wellbeing. 


\section{ACKNOWLEDGEMENTS}

This paper was written by Martin Walsh, Senior Researcher in Oxfam GB, and Solomon Mombeshora, Senior Lecturer in Development Studies at the Women's University in Africa, Harare, Zimbabwe. Research was undertaken as part of an ongoing collaboration between the Research and Programme Quality teams in Oxfam GB. Special thanks are due to Joseph Chaumba (Centre for Applied Social Sciences Trust, University of Zimbabwe) and many past and present Oxfam colleagues, especially Lynnette Tshabangu, Sekai Mativenga, Masimba Ndoro, Leonard Unganai, Cornelius Muchecheti, Tawanda Chinembiri, Machinda Marongwe and others at Oxfam Zimbabwe; Nicholas Ngepah and Musa Simelane in the Oxfam Southern Africa Region office; and David Bishop, Irene Guijt, Claire Hutchings, Simone Lombardini, John Magrath, and Ricardo Fuentes-Nieva. 
1 For an introduction to the Effectiveness Reviews and further information on their methodology and the reviews completed to date see http://policy-practice.oxfam.org.uk/our-work/methodsapproaches/project-effectiveness-reviews (this and other links cited in these notes were last accessed in June 2015). See also K. Hughes and C. Hutchings (2011) 'Can we obtain the required rigour without randomisation? Oxfam GB's non-experimental Global Performance Framework', Working Paper 13, International Initiative for Impact Evaluation (3ie),

http://www.3ieimpact.org/media/filer_public/2012/05/07/Working_Paper_13.pdf, C. Hutchings (2013) 'When we (rigorously) measure effectiveness, do we want accountability or learning? Update and dilemmas from an Oxfam experiment', http://oxfamblogs.org/fp2p/when-we-rigorously-measureeffectiveness-do-we-want-accountability-or-learning-update-and-dilemmas-from-an-oxfam-experiment/, D. Bishop and K. Bowman (2014) 'Still learning: a critical reflection on three years of measuring women's empowerment in Oxfam', Gender \& Development 22(2): 253-269, http://www.tandfonline.com/doi/pdf/10.1080/13552074.2014.920993, C. Hutchings (2014) 'Balancing accountability and learning: a review of Oxfam GB's global performance framework', Journal of Development Effectiveness 6(4): 425-435 http://www.tandfonline.com/doi/pdf/10.1080/19439342.2014.971552.

2 See, for example, the Karl Hughes' posts on Duncan Green's From Poverty to Power blog and the responses to them: K. Hughes (2011) 'Can we demonstrate effectiveness without bankrupting our $\mathrm{NGO}$ and/or becoming a randomista?', http://oxfamblogs.org/fp2p/can-we-demonstrate-effectivenesswithout-bankrupting-our-ngo-andor-becoming-a-randomista/; W. Savedoff (2012) 'Impact evaluations everywhere: what's a small NGO to do?', http://www.cgdev.org/blog/impact-evaluations-everywherewhat\%E2\%80\%99s-small-ngo-do; J. Richmond (2012) 'Tackling the evaluation challenge - how do we know if we're effective? ', http://policy-practice.oxfam.org.uk/blog/2012/10/effectiveness-reviews; K. Hughes (2012) 'When we (rigorously) measure effectiveness, what do we find? Initial results from an Oxfam experiment', http://oxfamblogs.org/fp2p/when-we-rigorously-measure-effectiveness-what-dowe-find-initial-results-from-an-oxfam-experiment/; N. York and K. Hoy (2012) 'What do DFID wonks think of Oxfam's attempt to measure its effectiveness?', http://oxfamblogs.org/fp2p/what-do-dfid-wonksthink-of-oxfams-attempt-to-measure-its-effectiveness/; J. Puri (2012) 'Getting evaluation right: a five point plan', http://oxfamblogs.org/fp2p/getting-evaluation-right-a-five-point-plan/

3 The first follow-up study was published as M. Walsh and R. Fuentes-Nieva (2014) 'Information Flows Faster Than Water: How livelihoods were saved in Pakistan's 2010 floods', Oxford: Oxfam GB, http://policy-practice.oxfam.org.uk/publications/information-flows-faster-than-water-how-livelihoodswere-saved-in-pakistans-201-317457

4 For background information on the project, see L. Tshabangu (2009) 'An Economic Analysis in the Context of Environmental Impact Assessment of an Irrigation Project in Gutu District, Zimbabwe', unpublished mini dissertation, Disaster Management Training and Education Centre for Africa (DiMTEC), University of the Free State, https://www.ufs.ac.za/docs/librariesprovider22/disastermanagement-training-and-education-centre-for-africa-(dimtec)-documents/dissertations/2263.pdf.

5 The summary of the Effectiveness Review in this and following paragraphs is based on Oxfam GB (2012a) 'Ruti Irrigation Project: Zimbabwe 2011/12', Project Effectiveness Reviews (snapshots), Oxford: Oxfam GB, http://oxfamilibrary.openrepository.com/oxfam/bitstream/10546/247851/1/erzimbabwe-effectiveness-review-081012-summ-en.pdf. The full report is D. Bishop, (2012) 'Ruti Irrigation Project Effectiveness Review: Full report', Oxford: Oxfam GB, http://oxfamilibrary.openrepository.com/oxfam/bitstream/10546/247851/6/er-zimbabwe-effectivenessreview-081012-en.pdf

6 Oxfam GB (2012b) 'Ruti Irrigation Scheme End of Project Evaluation Report', Harare: MEL Department, Oxfam GB. This evaluation was based on a Household Economy Approach (HEA) and data collected during a baseline reference period (November 2009 to October 2010) and the final year of the project (April 2011 to March 2012). It did not refer directly to the findings of the Effectiveness Review.

7 Oxfam GB (2012b), Op. cit., p. 1.

8 Bishop (2012), Op. cit., p. 3, and Oxfam GB (2012a), Op. cit., p. 2.

9 Oxfam GB (2012a), Op. cit., p. 2.

10 Bishop (2012), Op. cit., p. 33.

11 The follow-up study did not consider the health and hygiene training component of the project.

12 For details: S. Mombeshora, with J. Chaumba (2014) 'Tracing the Impacts of Ruti Irrigation Project in Gutu District, Zimbabwe', report to Oxfam Zimbabwe, Harare; and M. Walsh (2016) 'Using interpretive research to make quantitative evaluation more effective: Oxfam's experience in Pakistan and Zimbabwe', pp. 219-31 in S. Bell and P. Aggleton (eds.) Evaluation in Health and Social Development: Interpretive and Ethnographic Perspectives, Abingdon and New York: Routledge.

13 See J. Magrath (2014a) 'Adapting to a hotter, hungrier world in Zimbabwe', http://policypractice.oxfam.org.uk/blog/2014/03/adapting-to-a-hotter-hungrier-world-in-zimbabwe, J. Magrath (2014b) 'Irrigation Schemes and Weather Extremes: The Challenge for Zimbabwe', Oxford: Oxfam GB 
http://oxfamilibrary.openrepository.com/oxfam/bitstream/10546/322350/1/cs-Zimbabwe-irrigationscheme-Ruti-100714-en.pdf .

14 Bishop (2012), op. cit., pp. 28-30.

15 Oxfam GB (2012b), op. cit., pp. 10-11, 24. This includes data on increased yields, summarised on $\mathrm{p}$. 10 as follows: "Based on the survey the average production for phase 1 maize $(2010 / 2011$ agricultural season) was $994.4 \mathrm{kgs}$ ( $3.9 \mathrm{t}$ per hectare), with $600 \mathrm{kgs}$ being the lowest and $1600 \mathrm{kgs}$ being the maximum on the 0.25 ha plot. The dry land average harvest for the same season was $112.5 \mathrm{kgs}$ on an average 0.625 ha plot $(0.18 \mathrm{t}$ per hectare)." Production per household and yields per hectare vary (and have varied) from one season to another on the scheme, but are consistently higher than on dryland farms, where of course they also vary.

16 Oxfam GB (2012b), op. cit., pp. 9, 24.

17 Mombeshora (2014), Op. cit., Figure 18, p. 46, and information provided in Annex 1, pp. 79-107.

18 Mombeshora (2014), Op. cit., p. 104.

19 For details see Mombeshora (2014), Op. cit., § 3.2.4 'Food security and its key dimensions', pp. 35-45; also Oxfam GB (2012b), Op. cit., § 4.2 'Dietary diversity', pp. 8-9.

20 Mombeshora (2014), Op. cit., Annex 1, p. 96. US dollars were in use in Zimbabwe at the time of the Ruti project and its evaluation, and all references are to this currency. Although this farmer stated that she had harvested $320 \mathrm{~kg}$ of sugar beans in 2011, the subdivided amounts she gave added up to $335 \mathrm{~kg}$, which is therefore the total figure that we have used.

21 Mombeshora (2014), Op. cit., p. 93.

22 Mombeshora (2014), Op. cit., p. 24.

23 Ipaishe is not the woman of the same age whose sugar bean harvest and its use is shown in Figure 5.

24 Magrath (2014a), Op. cit., Magrath (2014b), Op. cit., p. 4, Oxfam Canada (2015) 'Ipaishe's story', https://www.oxfam.ca/blogs/ipaishes-story-zimbabwe; Oxfam International (2015) 'Determined, whatever the weather: Ipaishe's story', https://www.oxfam.org/en/multimedia/video/2015-determinedwhatever-weather-ipaishes-story; Oxfam International (2016) 'Ipaishe unlimited: one woman defied the expectations of her community - and took on the world's most powerful leaders to help end poverty', https://oxfam.exposure.co/ipaishe-unlimited

25 Mombeshora (2014), Op. cit., p. 59.

26 Mombeshora (2014), Op. cit., pp. 60, 82, 88.

27 Mombeshora (2014), Op. cit., p. 80.

28 Mombeshora (2014), Op. cit., pp. 100-101.

29 Oxfam GB (2012b), Op. cit., p. 18.

30 Oxfam in Zimbabwe's former Sustainable Livelihoods Coordinator, who has an intimate knowledge of the project and its farmers, comments as follows: 'I can imagine a methodology that traces indirect benefits along the Ruti irrigation food system would probably give a better picture of the indirect beneficiaries. So tracking the different pathways of benefits derived along the Ruti food value chain system, might give a better estimate of the indirect beneficiaries (e.g. there is also a primary school near the scheme, I can imagine its enrolment increasing as parents producing in the scheme opt to have their children attending this school for ease of supporting the children learning, and also benefits realized as children share food with friends at school)', Lynnette Tshabangu, personal communication (notes on an earlier draft of this paper), 19 April 2017.

31 Oxfam GB (2012b), Op. cit., pp. 15-16, Mombeshora (2014), Op. cit., pp. 34, 69, and interviews in Annex 1.

32 Mombeshora (2014), Op. cit., p. 95.

33 Magrath (2014b), Op. cit., pp. 3-4.

34 Phase 3 was also beset by more technical problems than the first two phases. The plots of Phase 1 and Phase 2 farmers were watered by gravity-fed irrigation, but there were problems in extending this to the Phase 3 farms. This problem was initially solved by the construction of overnight storage and installation of two solar booster pumps, provided under another Oxfam-supported initiative, the Rural Sustainable Energy Development (RuSED) Project (2011-16). However, the pumps broke down for nine months in 2013-14, and this had a further negative impact on the Phase 3 farmers. We are grateful to Cornelius Muchecheti for this information. Further details about the RuSED Project can be 
read in J. Magrath (2015a) 'Transforming Lives in Zimbabwe: Rural Sustainable Energy Development Project', Oxford: Oxfam GB,

http://oxfamilibrary.openrepository.com/oxfam/bitstream/10546/567000/1/cs-zimbabwe-solar-power-

170815-en.pdf

35 Mombeshora (2014), Op. cit., Figure 12, p. 34.

36 Mombeshora (2014), Op. cit., pp. 66-8.

37 The sugar estates also supply an ethanol plant. See D. Masunda (2011) 'Sugar cane lights up Middle Sabi', RadioVoP Zimbabwe, 13 July 2011, http://www.radiovop.com/index.php/blogs/6690-sugar-canelights-up-middle-sabi.html; ZINWA (2011) 'ZINWA major partner in Lowveld sugar industry', The Herald, 27 October 2011, http://www.herald.co.zw/zinwa-major-partner-in-lowveld-sugar-industry/; IUF (2013) 'Zimbabwe: Chisumbanje ethanol plant - politics and other stories', IUF Sugar Workers Network, http://www.iuf.org/sugarworkers/zimbabwe-chisumbanje-ethanol-plant-politics-stories/. For a wider view of the land conflicts that large-scale sugar production generates, see J. Thorpe (2013) 'Sugar Rush: Land Rights and the Supply Chains of the Biggest Food and Beverage Companies', Oxford: Oxfam, http://policy-practice.oxfam.org.uk/publications/sugar-rush-land-rights-and-the-supplychains-of-the-biggest-food-and-beverage-c-302505

38 For the El Niño event and Oxfam's wider response to it see J. Magrath (2015b) 'Entering Uncharted Waters: El Niño and the Threat to Food Security', Oxford: Oxfam GB, http://policy-

practice.oxfam.org.uk/publications/entering-uncharted-waters-el-nio-and-the-threat-to-food-security578822; D. Hillier and J. Magrath (2015) 'El Niño Key Messages: Urgent Action Now Can Prevent Major Suffering and Loss', Oxford: Oxfam GB, http://policy-practice.oxfam.org.uk/publications/el-niokey-messages-urgent-action-now-can-prevent-major-suffering-and-loss-582439; D. Hillier, J. Liebl and F. Mager (2015) 'El Niño: The Case for Urgent Action', Oxford: Oxfam GB, http://policypractice.oxfam.org.uk/publications/el-nio-the-case-for-urgent-action-583920; D. Hillier (2016) 'What Will Become of Us? Voices from Around the World on Drought and EI Niño', Oxford: Oxfam GB, http://policy-practice.oxfam.org.uk/publications/what-will-become-of-us-voices-from-around-the-worldon-drought-and-el-nio-605146; K. Hanks (2016) 'Hot, Hungry and Starved of Investment: Supporting Smallholders to Build a Climate-resilient Agricultural Sector in Southern Africa', Oxford: Oxfam GB, http://policy-practice.oxfam.org.uk/publications/hot-hungry-and-starved-of-investment-supportingsmallholders-to-build-a-climate-610600; C. Baudot and D. Hillier (2016) 'A Preventable Crisis: El Niño and La Niña Events Need Earlier Responses and a Renewed Focus on Prevention', Oxford: Oxfam GB, http://policy-practice.oxfam.org.uk/publications/a-preventable-crisis-el-nio-and-la-nia-events-needearlier-responses-and-a-rene-617022

39 Lynnette Tshabangu, personal communication, Harare, 2 March 2016.

40 See Mombeshora (2014), Op. cit. The interview transcripts in Annex 1, pp. 79-107, are particularly rich in information.

41 Walsh and Fuentes-Nieva (2014), Op. cit., p. 15. Ideally, integrated evaluations will also balance the requirements of accountability and learning and the needs of both country and global programmes. This can be especially challenging when priorities shift and programmes and personnel change, as they did during the course of this study.

42 Magrath (2014b), Op. cit., p. 1.

43 Mombeshora (2014), Op. cit., p. 11.

44 Oxfam International (2017) 'Oxfam in Zimbabwe', https://www.oxfam.org/en/countries/zimbabwe

45 Ruti has therefore recently been incorporated into the government of Zimbabwe's Command Agriculture scheme, a food security programme supporting productive smallholders and large-scale farmers to produce maize for the nation: Lynnette Tshabangu, personal communication, 19 April 2017. See 'Government introduces command agriculture', The Financial Gazette, 19 July 2016, http://www.zimbabwesituation.com/news/zimsit-m-government-introduces-command-agriculture/ 


\section{Oxfam Research Reports}

Oxfam Research Reports are written to share research results, to contribute to public debate and to invite feedback on development and humanitarian policy and practice. They do not necessarily reflect Oxfam policy positions. The views expressed are those of the author and not necessarily those of Oxfam.

For more information, or to comment on this report, email research@oxfam.org.uk

(c) Oxfam International October 2017

This publication is copyright but the text may be used free of charge for the purposes of advocacy, campaigning, education, and research, provided that the source is acknowledged in full. The copyright holder requests that all such use be registered with them for impact assessment purposes. For copying in any other circumstances, or for re-use in other publications, or for translation or adaptation, permission must be secured and a fee may be charged. Email policyandpractice@oxfam.org.uk

The information in this publication is correct at the time of going to press.

Published by Oxfam GB for Oxfam International under ISBN 978-1-78748-085-8 in October 2017.

Oxfam GB, Oxfam House, John Smith Drive, Cowley, Oxford, OX4 2JY, UK. DOI: 10.21201/2017.0858

\section{OXFAM}

Oxfam is an international confederation of 20 organizations networked together in more than 90 countries, as part of a global movement for change, to build a future free from the injustice of poverty. Please write to any of the agencies for further information, or visit www.oxfam.org

Oxfam America (www.oxfamamerica.org)

Oxfam Australia (www.oxfam.org.au)

Oxfam-in-Belgium (www.oxfamsol.be)

Oxfam Brasil (www.oxfam.org.br)

Oxfam Canada (www.oxfam.ca)

Oxfam France (www.oxfamfrance.org)

Oxfam Germany (www.oxfam.de)

Oxfam GB (www.oxfam.org.uk)

Oxfam Hong Kong (www.oxfam.org.hk)

Oxfam IBIS (Denmark) (www.ibis-global.org)
Oxfam India (www.oxfamindia.org)

Oxfam Intermón (Spain) (www.oxfamintermon.org)

Oxfam Ireland (www.oxfamireland.org)

Oxfam Italy (www.oxfamitalia.org)

Oxfam Japan (www.oxfam.jp)

Oxfam Mexico (www.oxfammexico.org)

Oxfam New Zealand (www.oxfam.org.nz)

Oxfam Novib (Netherlands) (www.oxfamnovib.nl)

Oxfam Québec (www.oxfam.qc.ca)

Oxfam South Africa (www.oxfam.org.za) 